\title{
FAKTOR-FAKTOR YANG MEMOTIVASI KECURANGAN LAPORAN KEUANGAN
}

\author{
Martdian Ratnasari \\ Sekolah Tinggi Manajemen PPM, Indonesia \\ martdianratnasari@gmail.com \\ M. Akhsanur Rofi \\ Sekolah Tinggi Manajemen PPM, Indonesia \\ m.akhsanur.rofi@gmail.com
}

\begin{abstract}
Abstrak
Laporan keuangan merupakan instrumen penting bagi setiap perusahaan. Laporan keuangan merupakan jendela informasi kondisi terkini keuangan perusahaan. Fungsi laporan keuangan yang sangat penting menjadikan laporan keuangan sebagai target manipulasi oleh individu yang memiliki niat untuk melakukan penipuan. Tak sedikit kasus kecurangan laporan keuangan disebabkan oleh faktor tekanan dan kesempatan yang dimiliki pelaku. Penelitian ini bertujuan untuk menganalisis pengaruh variabel-variabel dari teori diamond fraud yang dikemukakan oleh Wolfe dan Hermanson (2004) yaitu financial target, financial stability, external pressure, nature of industry, ineffective monitoring, change in auditor, total accrual dan capability terhadap financial statement fraud yang diproksikan dengan f-score model. Penelitian ini berfokus pada perusahaan milik negara dikarenakan perusahaan milik negara memiliki potensi yang sangat besar terhadap kecurangan dan korupsi. Pada penelitian ini sampel yang digunakan adalalah sebanyak 15 perusahaan BUMN non-bank yang telah listing di Bursa Efek Indonesia (BEI) pada periode 2011-2017. Jenis data yang digunakan adalah data sekunder berupa laporan tahunan perusahaan BUMN yang telah listing di BEI selama periode 2011-2015. Pengujian hipotesis dilakukan dengan metode regresi linier berganda. Hasil penelitian ini menunjukkan bahwa variabel target keuangan yang diproksi dengan return on asset terbukti berpengaruh positif dalam memotivasi kecurangan laporan keuangan. Variabel tekanan eksternal yang diproksi dengan rasio leverage terbukti memiliki efek negatif dalam memotivasi kecurangan laporan keuangan. Penelitian ini tidak membuktikan bahwa financial stability, ineffective monitoring, nature of industry, total accrual, change in auditor dan capability memiliki pengaruh dalam memotivasi financial statement fraud. Hasil penelitian ini juga membuktikan bahwa faktor yang sangat memengaruhi financial statement fraud adalah faktor tekanan. Maka dari itu, dapat disimpulkan variabel-variabel dalam fraud diamond dapat digunakan dalam memotivasi financial statement fraud.
\end{abstract}

Keywords: Fraud diamond, Financial statement fraud, Indonesia

\begin{abstract}
Financial statements are an important instrument for every company. Financial statements are a window of information on the company's current financial condition. The function of financial statements is very important to make financial reports as a target of manipulation by individuals who have the intention to commit fraud. Not a few cases of financial statement fraud caused by pressure and opportunity factors that have actors. This study aims to analyze the effect of variables from the diamond fraud theory proposed by Wolfe and Hermanson (2004), namely financial targets, financial stability, external pressure, nature of industry, ineffective monitoring, change in auditor, total accrual and capability of financial statements fraud proxied by the $f$-score model. This research focuses on state-owned companies because state-owned companies have enormous potential for fraud and corruption. In this study the sample used is 15 non-bank SOE companies that have been listed on the Indonesia Stock Exchange (IDX) in the 2011-2017 period. The type of data used is secondary data in the form of annual reports of BUMN companies that have been listed on the Indonesia Stock Exchange during the period 2011-2017. Hypothesis testing is done by using multiple linear regression methods. The results of this study indicate that the financial target variable which is proxied by return on assets is proven to have a positive effect in detecting financial statement fraud. The external pressure variable which is proxy by leverage ratio is proven to have a negative effect in detecting fraudulent financial statements. This study does not prove that financial stability, ineffective monitoring, nature of the industry, total accruals, change in auditors and capability have an influence in detecting financial statement fraud. The results of this study also prove that the factor that greatly influences the financial statement of fraud is the pressure factor. Therefore, it can be concluded that the variables in diamond fraud can be used in detecting financial statement fraud.
\end{abstract}

Keywords: Fraud diamond, Financial statement fraud, Indonesia 


\section{PENDAHULUAN}

Laporan keuangan akan berfungsi maksimal apabila disajikan sesuai dengan unsur-unsur kualitatifnya, antara lain: mudah dipahami, andal, dapat dibandingkan, dan relevan (Sihombing, 2014). Sehingga diperlukan laporan keuangan yang akurat, relevan, dan terhindar dari kecurangan untuk mendukung pengambilan keputusan pengguna laporan keuangan. Namun sayangnya, tidak semua pelaku bisnis sadar akan pentingnya laporan keuangan yang bersih dan terhindar dari kecurangan. Dan pada kenyataannya masih banyak perusahaan yang tidak dapat menyajikan laporan keuangan yang sesuai dengan kriteria PSAK.

Rezaee (2002) menyatakan bahwa dalam dua dekade terakhir kecurangan laporan keuangan telah meningkat secara substansial. Menurut Association of Certified Fraud Examiners (ACFE, Report to The Nation 2018) frekuensi tindakan kecurangan yang terjadi, dalam penyalahgunaan aset (asset misappropriation) merupakan tindakan kecurangan yang memiliki frekuensi tertinggi sebesar $80 \%$ disusul oleh korupsi (corruption) $51 \%$ dan yang terakhir adalah kecurangan laporan keuangan (financial statement fraud) sebesar 13\%. Namun kecurangan laporan keuangan adalah jenis kecurangan/fraud yang memiliki dampak kecurangan yang paling merugikan di antara jenis kecurangan lainnya dengan kerugian rata-rata sebesar $\$ 700.000,-$. Kecenderungan perusahaan melakukan kecurangan laporan keuangan biasanya didasari oleh tuntutan untuk senantiasa melakukan perbaikan dan peningkatan kinerja guna meningkatkan nilai perusahan yang nantinya akan disajikan di laporan keuangan. Atas dasar hal tersebut, perusahaan seringkali melakukan manajemen laba dengan berbagai cara untuk mempercantik laporan keuangan miliknya guna merebut hati para investor. Kecurangan akan selalu terjadi jika tidak ada pencegahan atau pendeteksian.

Menurut teori Cressey (1953), terdapat tiga kondisi yang selalu hadir dalam tindakan fraud yaitu pressure, opportunity, dan rationalization yang disebut sebagai fraud triangle. Wolfe dan Hermanson (2004) juga menyatakan hal yang sama bahwa untuk meningkatkan pencegahan dan pendeteksian fraud perlu unsur yang keempat yaitu "capability". Kecurangan tidak akan terjadi apabila tidak ada orang yang memiliki kemampuan untuk melaksanakan kecurangan 
tersebut (Wolfe dan Hermanson, 2004), sehingga terbentuk The New Fraud Diamond (Gbegi dan Adebisi, 2013, dalam Pardosi 2014). Hal ini sesuai dengan laporan ACFE 2018 yang menunjukkan bahwa hampir 26\% pelaku kecurangan berhubungan langsung dengan pihak executive.

Maraknya pemberitaan kasus fraud sampai dengan tahun 2018 juga dihadapi oleh beberapa perusahaan yang tergabung dalam Badan Usaha Milik Negara (BUMN) mulai dari pemberitaan tentang "Audit BPK menemukan 5.999 skandal BUMN dengan kerugian triliunan rupiah” (wartakota.tribunnews.com), "BUMN terindikasi Fraud" (www.republika.co.id), serta laporan KPK tahun 2011 juga menyebutkan bahwa terdapat pengaduan terhadap BUMN/BUMD sebanyak 36.001 kasus (www.bpk.go.id). Pemberitaan yang melibatkan BUMN tersebut semakin mendorong untuk dilakukannya penelitian atas deteksi kecurangan laporan keuangan terhadap perusahaan BUMN.

Penelitan mengenai kecurangan laporan keuangan perlu dilakukan untuk memberikan informasi terhadap motivasi perusahaan melakukan financial statement fraud, serta diharapkan dapat mendukung teori yang dikemukakan oleh Wolfe dan Hermanson (2004) yang menyatakan bahwa terdapat empat faktor kecurangan yaitu pressure, opportunity, rationalization dan capability yang merupakan alasan terjadinya fraud atau disebut dengan istilah fraud diamond. Fraud diamond juga diharapkan dapat menjadi media atau alat untuk mendeteksi kecurangan laporan keuangan sejak dini. Adapun urgensi dari penelitian ini adalah : (1) Sampel yang digunakan pada penelitian ini adalah perusahaan yang termasuk Badan Usaha Milik Negara (BUMN), sampel dipilih karena BUMN identik dengan pemberitaan kasuskasus kecurangan dan cenderung memiliki conflict of interest yang tinggi karena memiliki saham mayoritas; (2) Penelitian ini menggunakan fraud score model atau sering disebut $F$-Score dalam memotivasi kecurangan laporan keuangan. Fraud score model masih jarang digunakan karena banyak penelitian memotivasi kecurangan laporan keuangan melalui manajemen laba.

Hasil penelitian ini diharapkan dapat memberikan pandangan kepada manajemen sebagai agent terkait tanggung jawabnya dalam melindungi kepentingan principal 
dalam hal ini investor, dan hasil penelitian ini juga diharapkan dapat menjadi referensi para investor dalam menganalisis saham dan kinerja perusahaan.

\section{TINJAUAN TEORI DAN}

\section{PENGEMBANGAN HIPOTESIS}

\section{Kecurangan Laporan Keuangan}

\section{Kecurangan Laporan Keuangan}

merupakan tindakan yang disengaja dalam laporan keuangan sehingga berakibat pada salah saji material. Menurut Wells (2011) dalam Sihombing (2014), Kecurangan laporan keuangan mencakup beberapa modus, antara lain : (1) pemalsuan, pengubahan, atau manipulasi catatan keuangan (financial record), dokumen pendukung atau transaksi bisnis; (2) Penghilangan yang disengaja atas peristiwa, transaksi, akun, atau informasi signifikan lainnya sebagai sumber dari penyajian laporan keuangan; (3) Penerapan yang salah dan disengaja terhadap prinsip akuntansi, kebijakan, dan prosedur yang digunakan untuk mengukur, mengakui, melaporkan dan mengungkapkan peristiwa ekonomi dan transaksi bisnis; Penghilangan yang disengaja terhadap informasi yang seharusnya disajikan dan diungkapkan menyangkut prinsip dan kebijakan akuntansi yang digunakan dalam membuat laporan keuangan (Rezaee, 2002).

\section{Fraud Diamond}

Fraud Diamond merupakan gagasan baru atas fenomena fraud yang dikemukakan oleh Wolfe dan Hermanson (2004). Wolfe dan Hermanson (2004) menyatakan bahwa kecurangan tidak akan terjadi apabila tidak ada orang yang memiliki kemampuan untuk melakukan kecurangan tersebut, karena kecurangan terjadi berawal dari adanya tekanan. Ketika berada dalam kondisi tertekan, pelaku berusaha keluar dari tekanan tersebut dengan cara mencari kesempatan atau peluang. Selanjutnya yang membatasi seseorang untuk melakukan kecurangan adalah rasionalisasi. Apabila kecurangan yang dilakukan cukup memiliki rasionalisasi yang kuat, maka pelaku akan mengukur apakah dirinya mampu melakukan kecurangan tersebut. Kemampuan pelaku kecurangan tidak hanya berkaitan dengan keahliannya saja namun juga dalam hal wewenang dan kedudukannya di perusahaan. Maka dari itu, dikenalah teori Fraud Diamond yang mempertimbangkan faktor kapabilitas/kedudukan dalam melakukan 


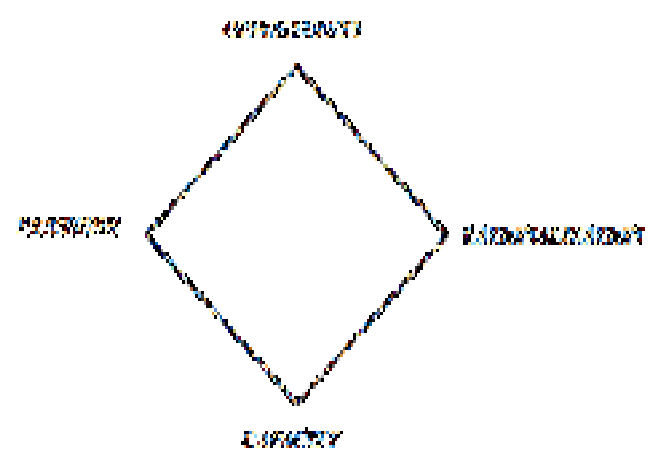

\section{Gambar 1. Fraud Diamond Theory oleh Wolfe dan Hermanson (2004)}

kecurangan sebagai faktor pendorong ke 4 yang memengaruhi perilaku kecurangan.

Berikut faktor-faktor yang memotivasi kecurangan laporan keuangan menurut Wolfe dan Hermanson (2004) :

\section{Pressure}

Pressure (tekanan) merupakan salah satu elemen penyebab terjadinya fraud yang digagas oleh Cressey (1953). Dalam hal ini pressure didefinisikan sebagai motivasi yang dapat mengarahkan seseorang bergerak melakukan tindakan fraud. Dalam Statement of Auditing Standards No. 99 terdapat empat jenis kondisi umum yang terjadi ketika pressure dan dapat mengakibatkan kecurangan. Kondisi tersebut adalah financial stability, external pressure, personal financial need, dan financial targets.

\section{Opportunity}

Opportunity/Peluang merupakan situasi yang memberikan kesempatan paling memungkinkan suatu kecurangan terjadi. Peluang dapat tercipta karena lemahnya internal control / pengawasan pada perusahaan. Di antara elemen fraud lainnya, opportunity merupakan elemen yang paling memungkinkan untuk diminimalisir melalui penerapan proses, prosedur dan control, serta upaya deteksi dini terhadap fraud. SAS No.99 menyebutkan bahwa peluang pada kecurangan laporan keuangan dapat terjadi pada tiga kategori kondisi. Kondisi tersebut adalah nature of industry, ineffective monitoring, dan organizational structure.

\section{Rationalization}

Rasionalisasi merupakan komponen penting dalam fraud yang menyebabkan pelaku kecurangan mencari pembenaran atas perbuatan yang dilakukannya. Rasionalisasi pada perusahaan dapat diukur dengan siklus pergantian auditor, opini audit yang didapat perusahaan tersebut, serta keadaan total akrual dibagi dengan total aktiva (Statement of Auditing Standards No.99). 


\section{Capability}

Menurut Wolfe dan Hermanson (2004), penambahan elemen keempat yaitu capability (kemampuan) diharapkan dapat meningkatkan kemampuan memotivasi dan mencegah terjadinya fraud. Posisi atau fungsi seseorang dalam sebuah perusahaan memungkinkan memberikan seseorang tersebut kemampuan untuk membuat atau mengeksploitasi suatu kesempatan menjadi tindak kecurangan di mana posisi dan kemampuan tersebut tidak dimiliki oleh orang lain, (Ruankaew, 2016). Wolfe dan Hermanson (2004) berpendapat fraud yang umumnya bernominal besar tidak mungkin terjadi apabila tidak ada orang tertentu dengan capability (kemampuan) khusus yang ada dalam perusahaan. Terdapat tiga hal yang dapat diamati dalam memprediksi kecurangan yaitu: 1) Posisi atau fungsi resmi dalam organisasi, 2) Kapasitas untuk memahami dan memanfaatkan sistem akuntansi dan kelemahan pengendalian internal, 3) Keyakinan bahwa dia tidak akan terdeteksi atau jika tertangkap dia akan keluar dengan mudah (Kassem dan Higson, 2012).

\section{Fraud Score Model}

Menurut Sukrisnadi (2010) Fraud score model atau yang lebih dikenal dengan $F$-Score merupakan suatu ukuran komposit yang diklaim dapat digunakan sebagai alat memotivasi salah saji material dalam laporan keuangan. Tujuan Dechow et al. (2007), membangun model F-Score yaitu untuk mengembangkan satu ukuran yang dapat secara langsung dihitung dari laporan keuangan. Komponen variabel pada F-Score meliputi dua hal yang dapat dilihat di laporan keuangan, yaitu accrual quality yang diproksikan dengan RSST (Richardson, Sloan, Soliman dan Tuna) accrual dan financial performance yang diproksikan dengan perubahan pada akun piutang, perubahan pada akun persediaan, perubahan pada akun penjualan tunai, perubahan pada EBIT. Model F-Score merupakan penjumlahan dari dua variabel yaitu accrual quality dan financial performance.

Model $F$-score ini dianggap lebih baik dalam mendeteksi kecurangan laporan keuangan, karena dalam model F-score ini lebih banyak menggunakan akun-akun keuangan yang bersifat akrual, yakni melihat pada kualitas akrual yang diproksikan dengan 
RSST akrual dan financial performance dengan mendefinisikan semua perubahan nonkas dan non ekuitas dalam neraca perusahaan sebagai akrual dan membedakan karakteristik keandalan working capital (WC), non-current operating (NCO) dan financial accrual (FIN) serta komponen aset dan kewajiban akrual.

Dalam penelitian ini, variabel-variabel yang digunakan dalam memotivasi kecurangan laporan keuangan sebagai proxy pressure/tekanan, opportunity / kesempatan, rationalization / rasionalisasi dan capability / kapabilitas yaitu, untuk faktor tekanan diproxikan dengan variabel financial target, financial stability, dan external pressure. Untuk faktor opportunity / kesempatan diproxikan dengan nature of industry dan ineffective monitoring. Untuk faktor rasionalization / rasionalisasi diproxikan dengan change of auditor dan total akrual. Dan untuk faktor capability diproxikan dengan pergantian direksi.

Manajemen selalu dituntut untuk memberikan kinerja terbaiknya. Salah satu ukuran kinerja manajemen adalah terkait pencapaian target dalam bentuk financial target. Financial target mencerminkan bagaimana manajemen bekerja secara efektif dan efisien dalam menghasilkan keuntungan yang bersumber dari pemanfaatan aset yang dimiliki perusahaan. Dengan adanya financial target manajemen termotivasi untuk mencapai setiap target yang sudah ditentukan, dan hal ini juga memotivasi manajemen untuk melakukan kecurangan laporan keuangan agar kinerjanya selalu terlihat baik. Selain financial target, financial stability juga diasumsikan dapat memotivasi manajemen melakukan kecurangan laporan keuangan, karena investor, kreditor maupun publik memiliki preferensi lebih terhadap perusahaan yang memiliki stabilitas keuangan yang baik. Hal ini menunjukkan bahwa perusahaan dituntut untuk memiliki stabilitas keuangan yang baik, sehingga manajemen akan cenderung mempercantik laporan keuangan untuk mempertahankan citra baik dari investor, kreditor maupun publik.

External pressure merupakan tekanan yang dihadapi oleh manajemen karena harus memenuhi persyaratan atau harapan dari pihak ketiga. Dengan kata lain, tekanan tersebut tidak berasal dari diri seorang manajer atau pemegang saham yang tercermin dari financial stability, personal financial need dan financial target (Iqbal dan Murtanto, 2016). Salah satu 
sumber tekanan eksternal adalah ketika dalam rangka meningkatkan sumber pendanaan untuk meningkatkan kinerja perusahaan, namun perusahaan kesulitan untuk memenuhi persyaratan kredit dan timbul kekhawatiran bahwa pada saat utang jatuh tempo, perusahaan tidak sanggup untuk mengembalikannya (Skousen dkk 2008). Hal tersebut menunjukkan bahwa jika semakin besar hutang yang dimiliki perusahaan, maka akan semakin tinggi juga potensi kecurangan laporan keuangan yang dilakukan manajemen.

Nature of industry dan ineffective monitoring merupakan proxy dari faktor opportunity/kesempatan dalam fraud diamond. Nature of industry merupakan cerminan ideal perusahaan dalam sebuah industri. Lingkungan ekonomi dan peraturan industri di suatu tempat perusahaan beroperasi, menjadi salah satu celah bagi perusahaan untuk melakukan praktik kecurangan laporan keuangan. Kerawanan tersebut timbul karena peraturan industri menuntut perusahaan untuk memiliki keahlian dalam melakukan estimasi terhadap akun-akun yang nilainya dihitung berdasarkan penilaian subjektif. Sedangkan untuk ineffective monitoring berkaitan erat dengan sistem pengawasan yang dimiliki perusahaan.
Perusahaan yang memiliki sistem pengawasan atau monitoring yang baik akan berdampak pada menurunnya potensi terjadinya praktik manipulasi laba yang dilakukan oleh agent atau manajemen (Andayani 2010). Namun sebaliknya, jika sistem pengawasan di perusahaan tidak baik, maka besar kemungkinan dijadikan celah dalam melakukan kecurangan.

Rationalization merupakan salah satu faktor yang tidak dapat dipisahkan dari potensi kecurangan laporan keuangan. Rationalization sering dihubungkan dengan sikap dan karakter seseorang yang membenarkan suatu tindakan yang tidak etis menurut masyarakat luas. Pelaku yang terlibat dalam kecurangan laporan keuangan secara konsisten merasionalisasi kecurangan tersebut dengan cara memodifikasi aturan/kode etik. Sikap atau anggapan tersebut semakin meningkat apabila auditor gagal memitigasi kecurangan laporan keuangan yang ada. Kegagalan audit dapat disebabkan oleh beberapa faktor, salah satunya adalah ketika terjadi pergantian auditor di perusahaan (Skousen et all. 2008). Hal ini disebabkan karena auditor eksternal yang baru masih belum mengerti kondisi perusahaan secara keseluruhan. Sehingga terdapat kecurangan 
yang dilakukan oleh manajemen yang tidak terdeteksi oleh auditor eksternal. Oleh karena itu, manajemen akan terus melakukan kecurangan laporan keuangan dan menganggap hal tersebut merupakan hal yang wajar karena tindakan kecurangan tersebut tidak menjadi temuan auditor eksternal.

Sedangkan untuk capability erat kaitannya dengan kemampuan individu untuk melakukan tindak kecurangan demi tercapainya tujuan tertentu. Wolfe dan Hermanson (2004) berpendapat bahwa kecurangan tidak akan terjadi apabila tidak ada orang yang memiliki kemampuan untuk melaksanakan kecurangan tersebut secara detail. Kemampuan seseorang dapat dinilai melalui keahliannya dalam melakukan kecurangan dan kedudukan/jabatannya di perusahaan. Oleh karena itu, posisi CEO, direksi, maupun kepala divisi lainnya dinilai paling mampu untuk mencegah atau sebaliknya yaitu memanfaatkan kemampuannya tersebut untuk melakukan kecurangan.

\section{Pengembangan Hipotesis}

Pengaruh Financial Target terhadap

Financial Statement Fraud

Adanya financial target yang menjadi tolak ukur kinerja seorang manajer menjadikan financial target sebagai salah satu tekanan bagi para manajer untuk memberikan kinerja terbaiknya. Salah satu alat ukur untuk mewakili Financial target dapat menggunakan return on asset. Return On Asset (ROA) adalah ukuran kinerja operasional yang sering digunakan dalam menunjukkan seberapa efisien aktiva telah bekerja. Menurut Dendawijaya (2005, dalam Sihombing, 2014) ROA merupakan alat ukur bagi manajemen perusahaan dalam memperoleh laba secara keseluruhan. Semakin besar ROA yang diperoleh, semakin besar pula tingkat keuntungan yang dicapai oleh perusahaan tersebut dan semakin baik pula posisi perusahaan tersebut dari segi penggunaan aset. Penelitian ini mencoba membuktikan bahwa financial target berpengaruh dalam memotivasi financial statement fraud. Berdasarkan uraian tersebut, diajukan hipotesis sebagai berikut: 


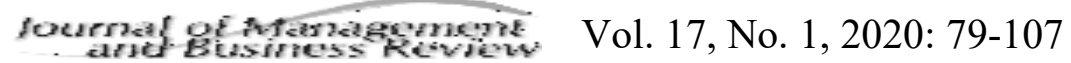

$\mathrm{H}_{1}$ : Financial Target berpengaruh dalam memotivasi Financial Statement Fraud

Pengaruh Financial Stability terhadap

Financial Statement Fraud

Kestabilan perusahan dapat meningkatkan nilai perusahaan dari sudut pandang investor, kreditor, serta publik. Ketidakstabilan kondisi keuangan pada suatu perusahaan menyebabkan manajemen cenderung mengalami tekanan, di mana hal tersebut dapat berdampak pada tindakan manajemen untuk melakukan kecurangan pada laporan keuangan.

Loebbecke et al. (1989), dan Bell et al. (1991), dalam Skousen et al. (2009) mengindikasikan bahwa ketika perusahaan sedang dalam masa pertumbuhan di bawah rata-rata industri, manajemen bisa saja memanipulasi laporan keuangan supaya performa perusahaan dapat meningkat. Menurut (Skousen et al., 2009) bentuk manipulasi pada laporan keuangan yang dilakukan oleh manajemen berkaitan dengan pertumbuhan aset perusahaan. Kondisi aset perusahaan yang menurun digambarkan sebagai ketidakstabilan kondisi keuangan perusahaan, yang mana ketika dalam keadaan tersebut manajemen cenderung mendapatkan tekanan dan mengarahkan perilakunya untuk memanipulasi laporan keuangan. Atas dasar hal tersebut, rasio perubahan total aset dijadikan proksi pada variabel financial stability. Semakin tinggi total aset perusahaan maka kekayaan yang dimiliki perusahaan semakin banyak. Berdasarkan uraian tersebut maka diajukan hipotesis sebagai berikut:

$\mathrm{H}_{2}$ : Financial Stability berpengaruh dalam memotivasi Financial Statement Fraud

\section{Pengaruh External Pressure terhadap}

\section{Financial Statement Fraud}

Adanya tekanan dari pihak eksternal perusahaan kerap kali dialami oleh manajemen perusahaan. Salah satu tekanan yang kerap kali dialami manajemen perusahaan adalah kebutuhan tambahan utang atau sumber pembiayaan eksternal agar perusahaan tetap kompetitif, termasuk untuk pembiayaan riset dan pengeluaran pembangunan atau modal (Skousen et al., 2009). Tambahan utang yang menjadi tanggung jawab manajemen nantinya akan menimbulkan adanya external pressure yang menyebabkan dorongan untuk melakukan tindakan kecurangan laporan keuangan. Dalam penelitian ini external 
pressure diproksikan dengan leverage ratio. Berdasarkan uraian diatas, diajukan hipotesis penelitain sebagai berikut:

$\mathrm{H}_{3}$ : External Pressure berpengaruh dalam memotivasi Financial Statement Fraud.

Pengaruh Nature of Industry terhadap

Financial Statement Fraud

Terdapat banyak perusahaan berkecimpung dalam industri yang melibatkan suatu estimasi dan pertimbangan. Penilaian estimasi tersebut memungkinkan manajemen melakukan tindakan yang menyimpang, misalnya pada akun-akun seperti piutang dan persediaan. Pada penelitian yang dilakukan oleh Summers and Sweeney (1998), ditemukan bahwa terdapat perbedaan kondisi akun piutang dan persediaan antara perusahaan yang melakukan fraud dengan yang tidak melakukan fraud. Menurut Summers dan Sweeney (1998), akun piutang dan persediaan memerlukan penilaian subjektif dalam memperkirakan tidak tertagihnya piutang. Summers dan Sweeney (1998) juga menyatakan apabila manajer ingin melakukan manipulasi terhadap laporan keungan, manajer akan fokus pada kedua akun tersebut. Penelitian yang dilakukan oleh Summers dan Sweeney (1998) menunjukkan bahwa rasio perubahan dalam piutang usaha yang merupakan proksi dari variabel nature of industry berpengaruh terhadap financial statement fraud. Ukuran ini dihitung sebagai rasio piutang terhadap penjualan di tahun $t$ dikurangi dengan rasio piutang terhadap penjualan di tahun $t-1$, di mana $t$ merupakan tahun sebelum terjadinya fraud. Berdasarkan uraian tersebut, diajukan hipotesis sebagai berikut:

$\mathrm{H}_{4}$ : Nature of Industry berpengaruh dalam memotivasi Financial Statement Fraud

Pengaruh Ineffective Monitoring terhadap

\section{Financial Statement Fraud}

Praktik kecurangan terjadi dapat disebabkan karena lemahnya monitoring atau pengawasan yang menyebabkan manajemen perusahaan memiliki kesempatan dan melakukan perilaku menyimpang. Umumnya perusahaan memiliki dewan komisaris yang bertugas untuk melakukan pengawasan dan memberikan nasihat kepada direktur perusahaan. Adanya dewan komisaris dipercaya dapat meningkatkan efektivitas terhadap pengawasan perusahaan. Dalam Sihombing (2014) menjelaskan bahwa dewan komisaris bertugas untuk menjamin terlaksananya strategi perusahaan, mengawasi 
manajemen dalam mengelola perusahaan serta mewajibkan terlaksananya akuntabilitas

(Forum for Corporate Governance in Indonesia, 2003). Penelitian ini memproksikan ineffective monitoring pada rasio jumlah dewan komisaris independen. Atas uraian tersebut, diajukan hipotesis sebagai berikut:

$\mathrm{H}_{5}$ : Ineffective Monitoring berpengaruh dalam memotivasi Kecurangan laporan keuangan

Pengaruh Change in Auditor terhadap Financial Statement Fraud

Menurut Lou dan Wang (2009), pergantian auditor merupakan cara untuk mengurangi kemungkinan pendeteksian kecurangan laporan keuangan oleh pihak auditor. Auditor lama cenderung lebih dapat memotivasi segala kemungkinan kecurangan yang dilakukan oleh manajemen, baik secara langsung maupun tidak langsung. Perubahan atau pergantian kantor akuntan publik yang dilakukan perusahaan dapat mengakibatkan masa transisi dan stress period melanda perusahaan. Jika setiap periode tahun berjalan perusahaan melakukan pergantian auditor terus menerus, hal tersebut dapat mengindikasikan bahwa manajemen melakukan fraud. SAS No.99 juga menyarankan perubahan auditor untuk dikaitkan dengan financial statement fraud. Berdasarkan uraian tersebut, diajukan hipotesis sebagai berikut:

$\mathrm{H}_{6}$ : Change in Auditor berpengaruh dalam memotivasi Kecurangan laporan keuangan

Pengaruh Total Accrual terhadap Financial

\section{Statement Fraud}

Prinsip akrual manajemen adalah konsep di mana pendapatan dan beban dicatat dan diakui ketika transaksi terjadi, bukan berdasarkan atas penerimaan kas. Skousen (2009) berpendapat bahwa rasio total akrual dapat digunakan untuk menggambarkan rasionalisasi terkait dengan penggunaan prinsip akrual oleh manajemen. Penggunaan prinsip akrual oleh manajemen menjadi celah yang dapat dimanfaatkan untuk menjalankan tindakan yang menyimpang, misalnya terdapat pendapatan fiktif guna memberikan angka yang diharapkan pada laporan keuangan. Tindakan menyimpang tersebut dapat dikategorikan sebagai financial statement fraud. Penjelasan di atas juga didukung oleh penelitian yang dilakukan oleh Sihombing (2014) yang menunjukkan bahwa Total Accrual berpengaruh signifikan dalam memotivasi financial statement fraud. 
Berdasarkan uraian di atas, diajukan hipotesis sebagai berikut:

$\mathrm{H}_{7}$ : Total accrual berpengaruh dalam memotivasi Financial Statement Fraud

Pengaruh Capability terhadap Financial

\section{Statement Fraud}

Capability merupakan elemen tambahan yang digagas oleh Wolfe dan Hermanson (2004) untuk melengkapi model fraud triangle dari Cressey (1953). Capability diartikan sebagai seberapa besar daya dan kapasitas dari seseorang untuk melakukan tindakan kecurangan di lingkungan perusahaan. Capability dianggap dapat berpengaruh terhadap tindakan fraud karena tanpa memiliki kemampuan dan kapasitas, sulit bagi seseorang untuk mendorong dirinya melakukan tindakan fraud. Pada penelitian ini, capability diproksikan dengan ada atau tidaknya perubahan direksi pada tahun terkait.

Direksi merupakan pihak yang memiliki kendali besar terhadap jalannya operasi bisnis pada suatu perusahaan. Perubahan direksi umumnya berkaitan dengan muatan politis dan kepentingan pihak-pihak tertentu yang memicu munculnya conflict of interest. Wolfe dan Hermanson (2004) pada penelitiannya

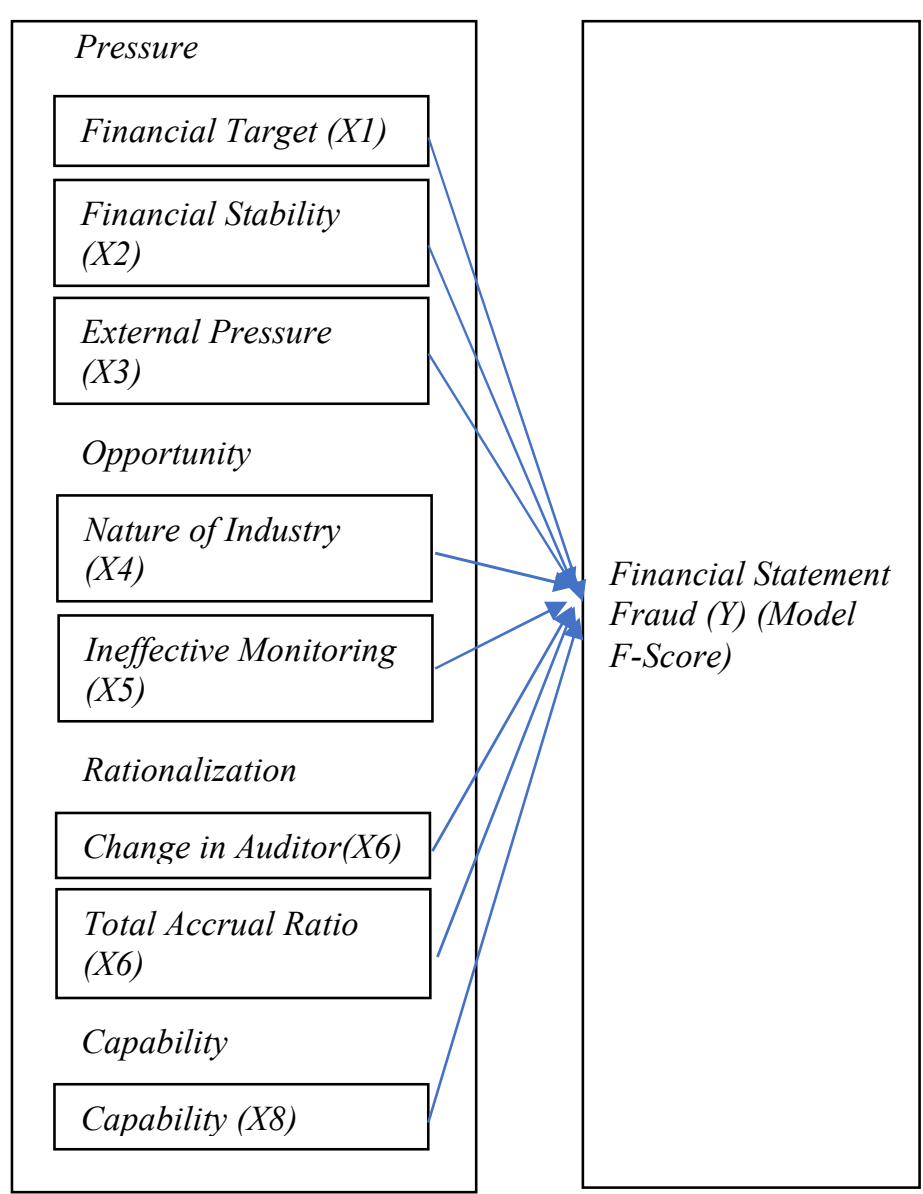

\section{Gambar 2. Kerangka Penelitian}

menyimpulkan bahwa perubahan direksi dapat menunjukkan terjadinnya tindakan fraud.

Berdasarkan uraian tersebut, diajukan hipotesis sebagai berikut :

$\mathrm{H}_{8}$ : Capability berpengaruh dalam memotivasi Financial Statement Fraud

\section{METODE RISET}

\section{Populasi, Sampel, dan Teknik pengambilan} sampel

Populasi dalam penelitian ini adalah perusahaan Badan Usaha Milik Negara (BUMN) yang listing di Bursa Efek Indonesia. 
Metode pengambilan sampel yang digunakan dalam penelitian ini adalah metode purposive sampling. Puposive sampling adalah pengambilan sampel secara sengaja sesuai dengan persyaratan sampel yang diperlukan. Berikut kriteria-kriteria yang digunakan dalam pengambilan sampel dalam penelitian ini antara lain: 1) Perusahaan Badan Usaha Milik Negara (BUMN) yang sudah terdaftar di bursa efek Indonesia pada tahun 2010-2017, 2) Perusahaan Badan Usaha Milik Negara (BUMN) selain bidang perbankan, 3) Mengungkapkan data-data yang berkaitan dengan variabel penelitian dan tersedia dengan lengkap (keseluruhan data tersedia pada publikasi selama periode 2010-2017), 4) Perusahaan yang sudah IPO sejak 2010.

\section{Definisi Operasional dan Pengukuran data} variabel

\section{Variabel Dependen}

Dalam penelitian ini pendeteksian kecurangan laporan keuangan menggunakan Fraud Score Model. Komponen variabel pada F-Score meliputi dua hal yang dapat dilihat di laporan keuangan, yaitu accrual quality yang diproksikan dengan perubahan non-kasdan non-ekuitas dalam suatu neraca perusahaan, financial performance yang diproksikan

$$
\begin{aligned}
F-\text { Score }= & \text { Accrual Quality }+ \\
& \text { Financial Performance }
\end{aligned}
$$

dengan perubahan pada akun piutang, perubahan pada akun persediaan, perubahan pada akun penjualan tunai, dan perubahan pada EBIT. Fraud Score Model merupakan penjumlahan dari dua variabel yaitu kualitas akrual dan kinerja keuangan.

\section{Accrual Quality}

Kualitas akrual diproksikan dengan RSST akrual (Richardson, Sloan,Soliman dan Tuna) yaitu dengan mendefinisikan semua perubahan non-kasdan non-ekuitas dalam suatu neraca perusahaan sebagai akrual dan membedakan karakteristik keandalan working capital (WC), non-currentoperating (NCO) dan financial accrual (FIN) serta komponen aset dan kewajiban dalam jenis akrual (Rini, 2012). Kualitas akrual diukur melalui RSST akrual dengan menghitung perubahan aset lancar (tidak termasuk kas), dikurangi perubahan dalam kewajiban lancar (tidak termasuk utang jangka pendek) dan penyusutan, juga memperhitungkan perubahan long-term operating assets dan long-term operating liabilities. Model perhitungannya adalah sebagai berikut: 
Keterangan:

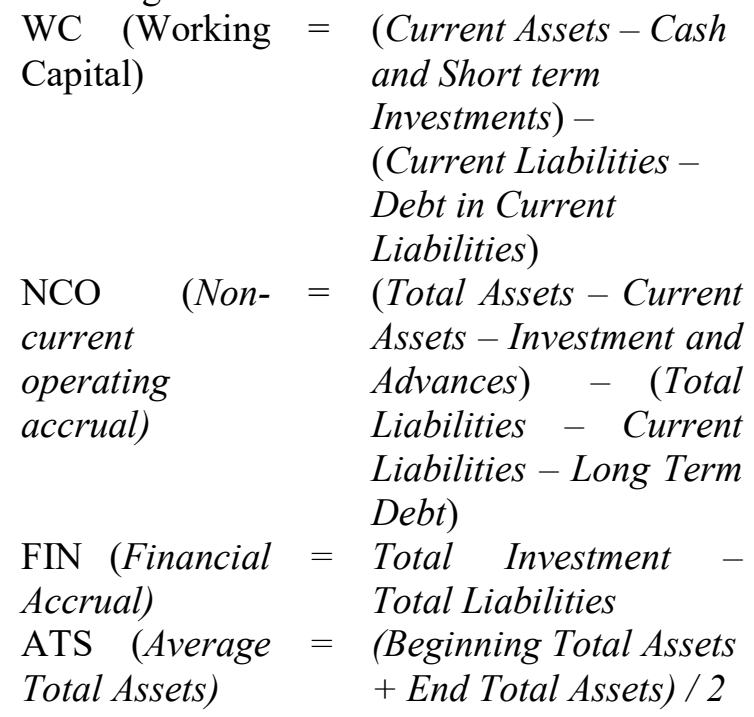

\section{Financial Performance}

Menurut Skousen (2009), financial performance dari suatu laporan keuangan mampu memprediksi terjadinya financial statement fraud, dengan model perhitungan yaitu :

\begin{tabular}{|c|c|}
\hline $\begin{array}{l}\text { Financial } \\
\text { performance }\end{array}$ & $\begin{aligned} &= \text { Change in Receivable + } \\
& \text { Change in Inventories }+ \\
& \text { Change in Cash Sales }+ \\
& \text { Change in Earnings }\end{aligned}$ \\
\hline
\end{tabular}

Keterangan:

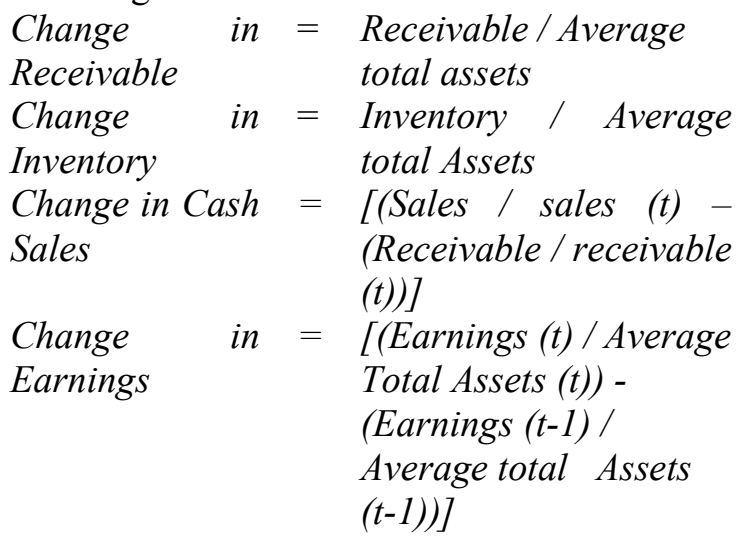

\section{Variabel Independen}

Pressure-Financial Target

Aktivitas perusahaan yang dijalankan seringkali memiliki target pada setiap periodenya. Target tersebut dapat berupa besaran laba yang diperoleh atas usaha yang dikeluarkan untuk mendapatkan laba tersebut. Kondisi seperti ini dinamakan financial target. ROA merupakan salah satu alat ukur untuk menilai tingkat laba yang diperoleh perusahaan atas usaha yang dikeluarkan (Sihombing, 2014). ROA digunakan untuk mengukur efektifitas perusahaan dalam menghasilkan keuntungan dengan memanfaatkan aktiva yang dimilikinya. ROA dapat dihitung dengan rumus sebagai berikut:

$$
\mathrm{ROA}=\frac{\text { Laba bersih sebelum pajak }}{\text { total aset }}
$$

\section{Financial Stability}

Financial stability adalah keadaan yang menggambarkan suatu perusahaan dalam kondisi stabil. Kestabilan kondisi perusahaan dapat dilihat dari bagaimana keadaan aset yang dimilikinya. FASB (1980, dalam Ghozali dan Chariri, 2007) mendefinisikan aset sebagai manfaat ekonomi yang mungkin terjadi di masa mendatang yang diperoleh atau dikendalikan oleh suatu entitas tertentu 
sebagai akibat transaksi atau peristiwa masa

lalu. Total aset menggambarkan kekayaan

yang dimiliki oleh perusahaan. Total aset meliputi aset lancar dan aset tidak lancar. Financial stability diproksikan dengan $A C H A N G E$ yang merupakan rasio perubahan total aset selama dua tahun. ACHANGE dihitung dengan rumus sebagai beirkut :

$$
\text { ACHANGE }=\frac{(\text { Total Aset } t-\text { Total Aset } t-1)}{\text { Total Aset } t}
$$

\section{External Pressure}

External Pressure merupakan tekanan yang berlebihan bagi manajemen untuk memenuhi persyaratan atau harapan dari pihak ketiga. Dalam mengatasi tekanan tersebut, perusahaan membutuhkan tambahan utang atau sumber pembiayaan eksternal agar tetap kompetitif, termasuk pembiayaan riset dan pengeluaran pembangunan atau modal (Skousen et al., 2009). Kebutuhan pembiayaan eksternal tersebut seringkali terkait dengan pembiayaan melalui hutang. Atas dasar hal tersebut, external pressure pada penelitian ini diproksikan dengan rasio Leverage (LEV). Leverage dihitung dengan rumus sebagai berikut:

$$
\text { LEVERAGE }=\frac{\text { Kewajiban }}{\text { Totalaset }}
$$

\section{Opportunity}

Kecurangan tidak akan terjadi apabila tidak terdapat peluang untuk melakukan kecurangan tersebut. Opportunity merupakan elemen yang paling memungkinan untuk diminimalisir melalui penerapan proses, prosedur dan control, serta upaya deteksi dini terhadap fraud dibandingkan dengan elemen fraud diamond lainnya. Pada penelitian ini terdapat dua variabel dalam komponen opportunity antara lain ineffective monitoring dan nature of industry.

\section{Ineffective monitoring}

Ineffective monitoring merupakan keadaan di mana perusahaan memiliki unit pengawas yang efektif memantau kinerja manajemen perusahaan. Ineffective monitoring diproksikan dengan BDOUT yang dirumuskan sebagai berikut:

$$
\text { BDOUT }=\frac{\text { Total Komisaris Independen }}{\text { Dewan Komisaris }}
$$

\section{Nature of industry}

Nature of industry merupakan keadaan ideal suatu perusahaan dalam industri. Dalam laporan keuangan terdapat akunakun tertentu di mana besar saldonya 
merupakan suatu estimasi yang ditentukan oleh perusahaan, misalnya adalah akun persediaan usang dan akun piutang tak tertagih. Pada penelitian ini nature of industry diproksikan dengan receivable yang merupakan rasio total piutang. receivable dirumuskan sebagai berikut:

$\boldsymbol{R E C E I V A B L E}=\frac{\text { receivablet }}{\text { sales } t}-\frac{\text { receivable } t-1}{\text { sales } t-1}$

\section{Rationalization-Total Accrual}

Menurut Skousen et al. (2009), penilaian dan pengambilan keputusan yang subjektif tersebut dapat tercermin dari nilai akrual perusahaan. Rasio total akrual (TATA) dapat dihitung dengan rumus perhitungan akrual oleh Beneish (1997) yaitu:

\section{TATA $=$ (Net Income from Continuing Operation - CF from Operation) / Total Asset}

\section{Change in auditor}

Penelitian ini memproksikan change in auditor dengan pergantian auditor external (AUDCHANGE) yang diukur dengan variabel dummy. Apabila terdapat perubahan Kantor Akuntan Publik selama periode 2011-2015 maka diberi kode 1 , sebaliknya apabila tidak terdapat perubahan kantor akuntan publik selama periode 2011-2015 maka diberi kode 0 .
Capability

Perubahan direksi akan dapat menyebabkan stress period yang berdampak pada semakin terbukanya peluang untuk melakukan fraud (Wolfe dan Hermanson, 2004). Oleh karena itu penelitian ini memproksikan capability dengan pergantian direksi perusahaan (DCHANGE) yang diukur menggunakan variabel dummy. Apabila terdapat perubahan direksi perusahaan selama periode 2011-2015 maka diberi kode 1, sebaliknya apabila tidak terdapat perubahan direksi perusahaan selama periode 2011-2015 maka diberi kode 0 .

\section{Metode analisis data}

Pada penelitian ini dilakukan Uji Normalitas untuk melihat apakah nilai residual terdistribusi normal atau tidak, dan uji asusmsi klasik yang bertujuan untuk memastikan bahwa hasil penelitian adalah valid dengan data yang digunakan secara teori adalah tidak bias, konsisten dan penaksiran koefisien regresinya efisien. Penelitian ini menggunakan analisis regresi berganda dengan menggunakan software SPSS Statistics 20. Model regresi yang digunakan adalah model regresi linier berganda. Berikut adalah model regresi dari 
hubungan antara kecurangan laporan keuangan dan proxi dari fraud diamond:

$\mathrm{F}-\mathrm{SCORE}=\mathrm{BO}+\mathrm{B1}$ ROA + B2 ACHANGE + B3LEV + ß4 RECEIVABLE

+ B5 BDOUT+ 36 AUDCHANGE+ B7

TATA+ B8DCHANGE $+\varepsilon i$

Keterangan:

\begin{tabular}{|c|c|c|}
\hline B0 & $=$ & $\begin{array}{l}\text { Koefisien Regresi } \\
\text { Konstanta }\end{array}$ \\
\hline$ß 1,2,3,4,5,6,7,8$ & $=$ & $\begin{array}{l}\text { Koefisien regresi } \\
\text { masing-masing proksi }\end{array}$ \\
\hline F-Score & $=$ & $\begin{array}{l}\text { Kecurangan Laporan } \\
\text { Keuangan }\end{array}$ \\
\hline ROA & $=$ & Return On Assets \\
\hline ACHANGE & $=$ & $\begin{array}{l}\text { Rasio perubahan total } \\
\text { aset tahun 2011-2015 }\end{array}$ \\
\hline LEV & $=$ & $\begin{array}{l}\text { Rasio total kewajiban } \\
\text { per total aset }\end{array}$ \\
\hline BDOUT & $=$ & $\begin{array}{l}\text { Rasio dewan komisaris } \\
\text { independen }\end{array}$ \\
\hline RECEIVABLE & $=$ & $\begin{array}{l}\text { Rasio perubahan } \\
\text { piutang usaha }\end{array}$ \\
\hline TATA & $=$ & $\begin{array}{l}\text { Rasio total akrual per } \\
\text { total aset }\end{array}$ \\
\hline AUDCHANGE & $=$ & $\begin{array}{l}\text { Pergantian Auditor } \\
\text { Independen }\end{array}$ \\
\hline CHANGE & $=$ & Pergantian Direksi \\
\hline
\end{tabular}

Untuk melakukan pengujian hipotesis pada penelitian ini, diperlukan uji koefisien determinasi $\left(\mathrm{R}^{2}\right)$ dan uji koefisien regresi secara parsial (t-test).

\section{HASIL PENELITIAN DAN}

\section{PEMBAHASAN}

Pada penelitian ini jumlah kesuluruhan sampel sebanyak 75. Pengambilan sampel pada penelitian ini menggunakan metode
Tabel 1. Kriteria Sampel Penelitian

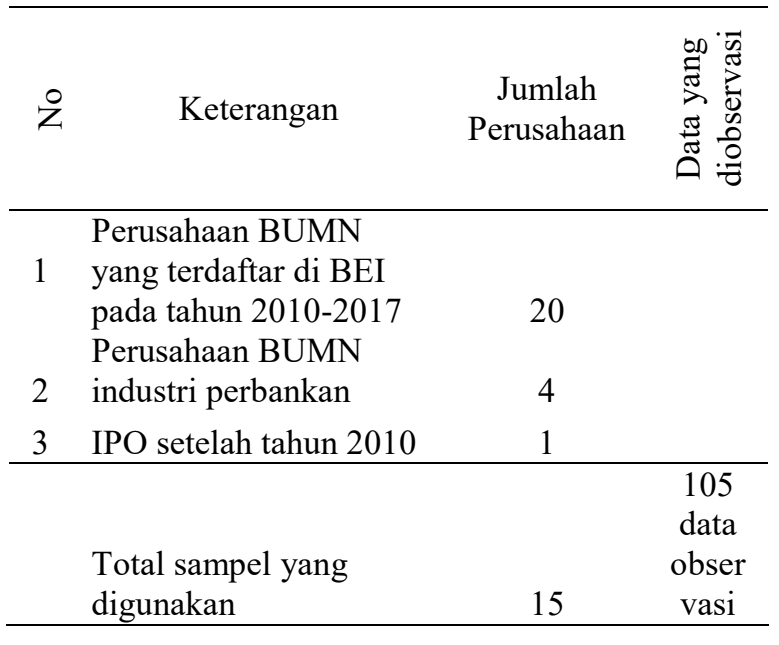

Tabel 2. Hasil Uji Koefisien Determinasi $\left(R^{2}\right)$

\begin{tabular}{ccccc}
\hline Model & $\mathrm{R}$ & $\begin{array}{c}\mathrm{R} \\
\text { Square }\end{array}$ & $\begin{array}{c}\text { Adjusted } \\
\mathrm{R} \\
\text { Square }\end{array}$ & $\begin{array}{c}\text { Std. } \\
\text { Error of } \\
\text { the } \\
\text { Estimate }\end{array}$ \\
\hline 1 &, $683^{\mathrm{a}}$ & 0,406 & 0,458 & 0,643201
\end{tabular}

a. Predictors: (Constant), CPB, NOI, FS, IM, TATA, EP, FT, CIA

b. Dependent Variable: FSC

Sumber : data yang diolah penulis

puposive sampling. Tabel 1 menunjukkan

rincian sampel yang digunakan dalam penelitian ini.

Melihat tabel 1, terdapat 15 sampel perusahaan dengan jumlah 105 data keuangan yang digunakan pada penelitian ini dengan tahun penelitian 2011-2017 (7 tahun). Adapun data yang digunakan dalam penelitian ini yaitu laporan keuangan dan laporan tahunan perusahaan sampel pada tahun 2010-2017. 
Tabel 3. Hasil Uji T

\begin{tabular}{|c|c|c|c|c|c|}
\hline & \multicolumn{2}{|c|}{$\begin{array}{l}\text { Unstandardized } \\
\text { Coefficients }\end{array}$} & \multirow{2}{*}{$\begin{array}{c}\begin{array}{c}\text { Standardized } \\
\text { Coefficients }\end{array} \\
\text { Beta }\end{array}$} & \multirow[t]{2}{*}{$\mathbf{T}$} & \multirow[t]{2}{*}{ Sig. } \\
\hline & $\mathbf{B}$ & Std. Error & & & \\
\hline (Constant) & 0,286 & 0,337 & & 0,851 & 0,398 \\
\hline Financial target & 1,601 & 0,747 & 0,244 & 2,144 & 0,036 \\
\hline Financial stability & 0,459 & 0,253 & 0,158 & 1,513 & 0,045 \\
\hline External pressure & 0,471 & 0,363 & 0,364 & $-3,077$ & 0,003 \\
\hline Nature of Industry & 0,022 & 0,076 & 0,543 & 0,296 & 0,768 \\
\hline Ineffective Moitoring & 0,142 & 0,234 & 0,067 & 0,608 & 0,545 \\
\hline Change in Auditor & 0,128 & 0,162 & 0,103 & 0,789 & 0,433 \\
\hline Total accrual & $-1,397$ & 0,967 & $-0,149$ & $-1,445$ & 0,153 \\
\hline Capability & $-0,036$ & 0,287 & $-0,015$ & $-0,125$ & 0,901 \\
\hline
\end{tabular}

Berdasarkan pengolahan data untuk uji normalitas dan uji asumsi klasik yang telah dilakukan, dapat dinyatakan bahwa data yang dipakai pada penelitian ini terdistribusi normal dan bebas dari penyimpangan asumsi klasik.

\section{Hasil Pengujian Hipotesis}

Berdasarkan hasil pengolahan data yang tertera pada tabel 2, angka $R$ square atau koefisien determinasi adalah sebesar 0,458. Hal ini menjelaskan bahwa fraud diamond yang terdiri dari pressure, opportunity, rationalization dan capability sebagai variabel independen dalam penelitian ini dapat menjelaskan variabel dependen sebesar $45,8 \%$, sedangkan sisanya $54,2 \%$ dipengaruhi oleh variabel lain yang tidak diteliti pada penelitian ini.
Dalam suatu penelitian uji $\mathrm{T}$ digunakan untuk menguji pengaruh variabel independen terhadap variabel dependen secara individu, sehingga dengan dilakukannya pengujian ini suatu penelitian dapat menyimpulkan apakah variabel independen yang diuji di dalam penelitian berpengaruh atau tidak berpengaruh terhadap variabel dependen yang ada. Hasil pengujian pada penelitian ini tertera pada tabel 3.

Berdasarkan tabel penghitungan uji $t$ di atas, berikut merupakan penjelasan dan pembahasan masing-masing variabel. 


\section{Financial target terhadap Financial}

\section{Statement Fraud}

Berdasarkan hasil pengolahan data yang tertera pada tabel di atas variabel financial target menunjukkan nilai sig sebesar 0,036 $(<0,05)$ yang menyatakan bahwa H0 ditolak dan H1 diterima sehingga dapat disimpulkan bahwa financial target berpengaruh dalam memotivasi financial statement fraud. Hasil dari pengujian tersebut mendukung penelitian yang telah dilakukan oleh Norbarani (2012) dan juga mendukung teori yang dikemukakan oleh Cressey (1953) yang menjelaskan bahwa tekanan berlebihan kepada manajemen untuk mencapai target keuangan yang diharapkan, dapat menyebabkan risiko kecurangan laporan keuangan dengan cara memanipulasi laporan tersebut agar sesuai dengan target yang telah direncanakan

Meningkatnya target keuangan perusahaan sangat mempengaruhi manajemen untuk melakukan kecurangan laporan keuangan. Hal tersebut terjadi karena ketika perusahaan ingin meningkatkan profitabilitasnya, pasti juga akan mempertimbangkan untuk meningkatkan mutu operasional yang dimiliki. Perusahaan akan ragu untuk melakukan investasi berupa modernisasi sistem informasi di perusahaan, pengefisienan proses bisnis yang dianggap memboroskan, merekrut tenaga ahli, dan menerapkan kebijakan-kebijakan lain guna mencapai target yang telah ditetapkan.

\section{Financial stability terhadap Financial}

\section{Statement Fraud}

Berdasarkan hasil pengolahan data yang tertera pada tabel 3, variabel financial stability menunjukkan nilai sig sebesar $0,045(<0,05)$ yang menyatakan bahwa $\mathrm{H} 0$ ditolak dan $\mathrm{H} 2$ diterima sehingga dapat disimpulkan bahwa financial stability berpengaruh dalam memotivasi financial statement fraud. Hasil dari pengujian tersebut mendukung teori yang dikemukakan oleh Cressey (1953) bahwa financial stability mempengaruhi financial statement fraud. Hal tersebut dapat terjadi karena yang menjadi sampel pada penelitian ini adalah perusahaan BUMN yang memiliki kendali besar dalam memegang bisnis perekonomian Indonesia. Selain itu, dilihat dari tahun penelitian yang digunakan yaitu tahun 2011-2017 bahwa secara makro menurut informasi yang didapat dari www.wsa.bi.go.id pada tahun tersebut perekonomian Indonesia 
cenderung tidak stabil dan semakin memburuk.

\section{Ketika kondisi keuangan sebuah} perusahaan tidak stabil, akan terjadi penurunan potensi kecurangan laporan keuangan. Hal tersebut terjadi karena perusahaan memiliki early warning system yang baik terhadap kestabilan keuangannya. Hasil ini menunjukkan kinerja dewan komisaris dan auditor internal sangat baik dalam mengawasi segala tindakan yang dilakukan manajemen, khususnya yang berhubungan dengan keuangan. Selain itu, nilai pertumbuhan aset di perusahaan menunjukkan nilai pertumbuhan yang sebenarnya, sehingga bukan karena adanya manipulasi. Jadi, walaupun kondisi keuangan perusahaan tidak stabil, manajemen tidak akan melakukan kecurangan. Ketika mengalami keadaan seperti ini, perusahaan harus terus mempertahankan ataupun menambahkan sistem pengawasan yang baik, agar manajemen tidak terganggu dengan fluktuatifnya stabilitas keuangan perusahaan dan tidak tergoda untuk melakukan kecurangan.

Sehingga perusahaan yang menjadi sampel pada penelitian ini besar kemungkinan menerima tekanan yang berlebihan yang ditujukan untuk menstabilkan keuangan perusahaan dan berdampak pada terjadinya risiko kecurangan laporan keuangan. Oleh karena itu pada penelitian ini untuk sampel perusahaan BUMN membuktikan bahwa financial stability memiliki pengaruh dalam memotivasi financial statement fraud.

\section{External pressure terhadap Financial}

\section{Statement Fraud}

Berdasarkan hasil pengolahan data yang tertera pada tabel 3, variabel external pressure menunjukkan nilai sig sebesar $0,003(<0,05)$ yang menyatakan bahwa $\mathrm{H} 0$ ditolak dan $\mathrm{H} 3$ diterima sehingga dapat disimpulkan bahwa external pressure berpengaruh dalam memotivasi financial statement fraud. Pengujian hipotesis pada penelitian ini mendukung penelitian yang telah dilakukan oleh Norbarani (2012). Manajemen menganggap bahwa tekanan yang berasal dari utang tidak mempengaruhi mereka untuk melakukan kecurangan. Hal ini terjadi karena perusahaan cenderung memilih melakukan penerbitan saham untuk menambah modalnya daripada melakukan perjanjian utang sehingga akan mengurangi tekanan untuk mengembalikannya di suatu hari nanti, dan 
mencegah tekanan yang dapat menimbulkan kecurangan. Namun ada juga perusahaan yang cenderung memilih untuk menambah pendanaannya melalui utang. Perusahaan ini memiliki keyakinan apabila mereka mendapatkan suntikan modal yang sumbernya dari utang, proses bisnis di perusahaan akan semakin baik dan meningkat sehingga akan mendapatkan pengembalian yang lebih tinggi atas usahanya dan dapat mengembalikan utang tersebut dengan lancar, serta akan mencegah adanya potensi tindak kecurangan laporan keuangan.

Hasil dari pengujian tersebut dapat diterima sebagaimana diketahui sampel pada penelitian ini yaitu perusahaan BUMN yang merupakan perseroan terbatas dan modalnya terbagi dalam saham di mana seluruh atau paling sedikit $51 \%$ sahamnya dimiliki oleh negara Republik Indonesia. Atas dasar kepemilikan saham tersebut kinerja perusahaan BUMN cenderung akan lebih banyak diawasi, tidak hanya dari pihak internal namun juga pihak oleh pihak-pihak eksternal perusahaan. Oleh karena itu dapat disimpulkan semakin tinggi tekanan dari pihak luar yang diberikan untuk perusahaan, maka perusahaan akan lebih berhati-hati untuk meminimalisir terjadinya kecurangan laporangan keuangan.

\section{Nature of Industry terhadap Financial}

\section{Statement Fraud}

Berdasarkan hasil pengolahan data yang tertera pada tabel 3, variabel nature of industry menunjukkan nilai sig sebesar $0,768(>0,05)$ yang menyatakan bahwa $\mathrm{H} 0$ diterima dan $\mathrm{H} 4$ ditolak sehingga dapat disimpulkan bahwa nature of industry tidak berpengaruh financial statement fraud. Hasil dari pengujian ini mendukung penelitian yang telah dilakukan oleh Sihombing (2014) dan Pardosi (2014). Namun penelitian ini tidak mendukung penelitian yang dilakukan oleh Summers dan Sweeney (1998) bahwa rasio perubahan dalam piutang usaha yang merupakan proksi dari variabel nature of industry berpengaruh terhadap financial statement fraud. Dari data yang diolah, tidak terdapat perubahan piutang usaha dari tahun sebelumnya sehingga tidak berpengaruh terhadap perputaran kas yang dapat mendorong manajemen melakukan financial statement fraud. Sehingga dapat disimpulkan kembali bahwa pada penelitian ini, nature of industry tidak berpengaruh dalam memotivasi financial statement fraud. 


\section{Ineffective monitoring terhadap Financial}

\section{Statement Fraud}

Berdasarkan hasil pengolahan data yang tertera pada tabel 3, variabel ineffective monitoring menunjukkan nilai sig sebesar $0,545(>0,05)$ yang menyatakan bahwa H0 diterima dan H5 ditolak sehingga dapat disimpulkan bahwa ineffective monitoring tidak berpengaruh dalam memotivasi financial statement fraud. Hasil penelitian ini mendukung penelitian sebelumnya yang telah dilakukan oleh Sihombing (2014).

Ineffective monitoring yang diproksikan dengan rasio jumlah dewan komisaris independen dalam penelitian ini tidak memiliki pengaruh dalam memotivasi kecurangan laporan keuangan. Hal ini mungkin saja dapat terjadi, dijelaskan bahwa fungsi dari dewan komisaris pada perusahaan BUMN yaitu melakukan pengawasan dan memberikan nasihat terkait kebijakankebijakan yang dijalankan perusahaan. Namun selepas dari itu, jalannya kebijakan-kebijakan perusahaan akan diawasi langsung oleh pihak direksi perusahaan. Sehingga pengawasan yang dijalankan tidak dapat hanya karena faktor dari jumlah dewan komisaris tetapi juga faktor pengawasan terhadap mekanisme yang diterapkan perusahaan agar berjalan dengan baik. Oleh karena itu pada penelitian ini ineffective monitoring tidak berpengaruh dalam memotivasi financial statement fraud.

\section{Change In Auditor terhadap Financial}

\section{Statement Fraud}

Berdasarkan hasil pengolahan data yang tertera pada tabel 3, variabel change in auditor menunjukkan nilai sig sebesar 0,433 $(>0,05)$ yang menyatakan bahwa H0 diterima dan H6 ditolak sehingga dapat disimpulkan bahwa change in auditor tidak berpengaruh dalam memotivasi financial statement fraud.

Perusahaan yang sering melakukan pergantian auditor cenderung terindikasi melakukan kecurangan pada laporan keuangan, hal tersebut dikarenakan temuan yang ditemukan oleh KAP sebelumnya dapat dimanipulasi oleh manajemen hingga KAP baru yang melakukan audit pada tahun berikutnya tidak dapat memotivasi temuan tersebut. Namun, pada penelitian ini hal tersebut tidak dapat dibuktikan karena perusahaan BUMN cenderung menggunakan auditor yang sama setiap 5-6 tahun. 
Total Accrual terhadap Financial Statement

Fraud

Berdasarkan hasil pengolahan data yang tertera pada tabel 3, variabel total accrual menunjukkan nilai sig sebesar $0,153(>0,05)$ yang menyatakan bahwa $\mathrm{H} 0$ diterima dan $\mathrm{H} 7$ ditolak sehingga dapat disimpulkan bahwa total accrual tidak berpengaruh negatif dalam memotivasi financial statement fraud. Hasil dari penelitian ini tidak mendukung penelitian yang dilakukan oleh Sihombing (2014) dan teori yang dikemukakan oleh Skousen (2009).

Pada dasarnya prinsip akrual pada manajemen diperbolehkan menurut PSAK, namun terdapat beberapa kasus kecurangan laporan keuangan yang menarik prinsip akrual menjadi salah satu pembenaran dalam melakukan kecurangan laporan keuangan. Pada penelitian ini, total accrual terbukti tidak berpengaruh dalam memotivasi financial statement fraud. Hal ini dapat disebabkan karena sampel yang digunakan dalam penelitian ini menghindari penggunaan prinsip akrual yang salah dalam menyajikan laporan keuangan. Sampel pada penelitian ini merupakan perusahaan yang memiliki kecenderungan untuk selalu diperhatikan terhadap apa yang disajikan, karena terdapat banyak pihak-pihak yang memiliki kepentingan dalam setiap angka yang disajikan pada laporan keuangan. Atas dasar hal tersebut dapat disimpulkan bahwa pada penelitian yang menggunakan sampel perusahaan BUMN industri non bank ini untuk variabel total accrual terbukti tidak berpengaruh dalam memotivasi financial statement fraud.

\section{Capability terhadap Financial Statement}

\section{Fraud}

Berdasarkan hasil pengolahan data yang tertera pada tabel, variabel capability menunjukkan nilai sig sebesar $0,901 \quad(>0,05)$ yang menyatakan bahwa $\mathrm{H} 0$ diterima dan $\mathrm{H} 8$ ditolak sehingga dapat disimpulkan bahwa capability tidak berpengaruh dalam memotivasi financial statement fraud. Hasil penelitian ini tidak mendukung teori yang dikemukakan oleh Wolfe dan Hermanson (2004) bahwa capability berpengaruh terhadap financial statement fraud. Perubahan direksi umumnya berkaitan dengan muatan politis dan kepentingan pihak-pihak tertentu yang memicu munculnya conflict of interest. Sampel yang digunakan dalam penelitian ini yaitu perusahaan BUMN yang memang memiliki conflict of interest yang tinggi. 
Namun perusahaan BUMN juga merupakan

figur perusahaan yang menjadi sorotan publik sehingga cenderung lebih berhati-hati dalam menyajikan laporan keuangan. Atas dasar hal tersebut dalam penelitian ini capability tidak berpengaruh dalam memotivasi financial statement fraud.

\section{KESIMPULAN DAN SARAN}

\section{Kesimpulan}

Penelitian ini bertujuan untuk mengetahui faktor-faktor yang memotivasi financial statement fraud dengan menggunakan analisis fraud diamond. Fraud diamond merupakan teori yang dikemukakan oleh Wolfe dan Hermanson (2004), fraud Diamond adalah suatu bentuk ekspansi sebagai penyempurnaan dari teori yang digagas oleh Donald R. Cressey (1953). Sampel yang digunakan dalam penelitian ini yaitu perusahaan BUMN yang terdaftar di BEI pada tahun 2011-2015 dengan menerapkan metode puposive sampling. Pada penelitian ini terdapat 8 faktor yang digunakan untuk memotivasi financial statement fraud, yaitu financial target, financial stability, external pressure, ineffective monitoring, nature of industry, change in audito, total accrual, dan capability.

Berdasarkan hasil penelitian, dapat disimpulkan bahwa financial targe, financial stabilityt dan external pressure berpengaruh dalam memotivasi financial statement fraud. Financial stability, ineffective monitoring, nature of industry, total accrual, change in auditor dan capability tidak berpengaruh dalam memotivasi financial statement fraud. Dari hasil penelitian ini membuktikan bahwa faktor tekanan merupakan faktor yang utama dalam memotivasi pelaku melakukan kecurangan laporan keuangan.

\section{Saran}

Berdasarkan kesimpulan dan keterbatasan dalam penelitian ini, maka saran yang akan diberikan untuk penelitian selanjutnya antara lain:

1. Diharapkan dapat menambah jumlah sampel atau meneliti perusahaan dari sektor lain, sehingga akan lebih valid dalam hasil yang diperoleh.

2. Periode penelitian sebaiknya diperluas sehingga hasil penelitian dapat memprediksi secara jangka panjang 


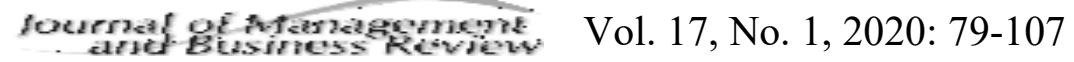

3. Dalam penelitian ini variabel variabel proksi dari fraud diamond agar independen yang digunakan hanya dapat cakupan variabel penelitian menjadi mewakili 45,8\% dari financial statement lebih luas, misalnya proksi personal fraud, sehingga diharapkan untuk financial need.

penelitian selanjutnya dapat menambah 


\section{DAFTAR PUSTAKA}

AICPA. "99: Consideration of Fraud Financial Statement Audit." Statement on Auditing Standards, 2002: 40.

Arrens, and Lobbecke. Auditing Pendekatan Terpadu . Jakrta: Salemba Empat, 1997.

Association of Certified Fraud Examiners. "Report to The Nation on Occupational Fraud and Abuse." Austin, USA, 2016.

Aziz, Nur Alimin. Teori Keagenan dan Implementasi Corporate Governance terhadap Manajemen Laba. Makassar: STIE-YPUP Makassar, 2016.

Belkaoui, Ahmed. Teori Akuntansi, Edisi ke 2. Jakarta: Erlangga, 1993.

Brennan, Niamh, and Mary Mc Grath. "Financial statement fraud : some lesson from US and European case studies." Australian Accounting Review (wiley blackwell), 2007: 17.

Board, Auditing Standards. "Consideration of Fraud in a Financial Statement Audit." Statement on Auditing Standards 99, 2002: 40.

Dechow, Patricia. Predicting Material Accounting Misstatement. Berkeley : University of Calofornia, $2007,31$.

Florenz C. Exploring a New Element of Fraud: A study on Selected Financial Accounting Fraud Cases in the World. Manilla, Philipines : De Lasalle University, 2012.

Intal, Tiina, and Linh Thuy Do. Financial Statement Fraud : Recognition of Revenue and The Auditor's Responsibility for Detecting Financial Statement Fraud. Goteborg University: School of Economics and Commercial Law, 2002.

Jensen, Michael C., and William H. Meckling. "Theory of The Firm : Managerial Behavior, Agency Cost and Ownership Structure." Journal of Financial economics Volume 3, 1976.

Kaseem, Rasha, and Andrew Highson. "The New Fraud Triangle Model." Journal of Emerging Trends in Economics and Management Sciences , 2012: 191-195.

Keuangan, Dewan Standar Akuntansi. Pernyataan Standar Akuntansi Keuangan . Jakarta: Ikatan Akuntansi Indonesia, 2013. 
Koroy, Tri Ramayana. Pendeteksian Kecurangan (Fraud) Laporan Keuangan oleh Auditor Eksternal. Banjarmasin: SIE Nasional Banjarmasin, 2008.

Lou, Yung-I, and Ming Long Wang. "Fraud Risk Factors of the Fraud Triangle Assesing the Likelihood of Fraudulent Financial Reporting ." Journal of Business \& Economics Research Volume 7 Number 2, 2009: 18.

Manurung, Daniel T.H, and Andhika Linggar Handika. Analysis of factors that influence financial statement fraud in the perspective fraud diamond; empirical study on banking companies listed on the Indonesia Stock Exchange year 2012-2014. Bandung: Universitas Widyatama, 2015.

Mansoor, Rabiuu Abdullahi Noorhayati. "Forensic Accounting and Fraud Risk Factors : The Influence of Fraud Diamond Theory." The American Journal of Innovative Research and Applied Sciences, 2015: 7.

Norbarani, Listiana. Pendeteksian Kecurangan Laporan Keuangan Dengan Analisis Fraud Triangle yang diadopsi dalam SAS No. 99. Semarang: Universitas Diponegoro, 2012.

Pardosi, Rica Widya. Analisis Fraud Diamond dalam Mendeteksi Kecurangan Laporan Keuangan pada Perusahaan Manufaktur di Indonesia dengan menggunakan Fraud Score Model (Tahun 2010-2013). Lampunng: Universitas Lampung, 2014.

Rezaee, Zabihollah. "Causes, Consequences, and deterence of Financial Statemnet Fraud." Critical perspective on accounting, 2002: 3 .

Rini, Viva Yustitia. Analisis Prediksi Potensi Risiko Fraudulent Financial Statement melalui Fraud Score Model . Semarang: Universitas Diponegoro, 2012.

Santoso, Purbayu Budi, and Ashari. Analisis statistik dengan Microsoft Excel dan SPSS. Yogyakarta: ANDI, 2005.

Sihombing, Kennedy Samuel. Analisis Fraud Diamond Dalam Mendeteksi Financial Statement Fraud : Studi Empiris pada Perusahaan Manufakturyang terdaftar di Bursa Efek Indonesia (BEI) Tahun 210-2012. Semarang: Universitas Diponegoro, 2014.

Sukrisnadi, Dedy. Pemakaian Ukuran F-Score dalam Kasus-Kasus Salah Saji Laporan Keuangan di Pasar Modal indonesia. Jakarta: Universitas Indonesia, 2010. 
Summers, Scott L., and John T. Sweeney. "Fraudulently Misstated Financial Statements and Insider Trading : An Empirical Analysis." The Accpunting Review Vol 73, 1998: 16.

Skousen, Christopher J. Detecting and Predicting Financial Statement Fraud: The Effectiveness of the Fraud Triangle and SAS N0.99. Huntsmant School of Business, 2009.

Thanasak Ruankaew, PhD. "Beyond the Fraud Diamond." International Journal of Business Management and Economic Research (Global Campus Colorado), 2016: 3.

Tuanakotta, Theodorus M. Akuntansi Forensik \& Audit Investigatif. Jakarta: Salemba Empat, 2016.

Ujiyantho, Muh Arief, and Bambang Agus Pramuka. "Mekanisme Coporate Governance, Manajemen Laba dan Kinerja Keuangan." Simposium Nasional Akuntansi X. Makassar: Universitas Hasanudin, 2007. 26.

Widarjono. Ekonometrika: Teori dan Aplikasi untuk Ekonomi dan Bisnis. Yogyakarta: Fakultas Ekonomi Universitas Islam Indonesia, 2007.

Wolfe, David T., and R. Hermanson Dana. "The Fraud Diamond: Considering the Four Elements of Fraud." The CPA Journal , 2004: 5.

Yesiariani, Merissa, and Isti Rahayu. Analisis Fraud Diamond dalam Mendeteksi Financial Statement Fraud (Studi empiris perusahaan LQ-45 yang terdaftar di Bursa Efek Indonesia Tahun 20102014). Yogyakarta: Universitas Islam Indonesia, 2015.

Republika. 2015. http://www.republika.co.id/berita/koran/pro-kontra/15/04/08/nmh7fp38-bumnterindikasi-fraud (accessed mei 2017).

Warta Kota. 2015. http://wartakota.tribunnews.com/2015/11/13/audit-bpk-temukan-5999-skandalbumn-dengan-kerugian-triliunan-rupiah (accessed mei 2017).

Blogspot. 2009. https://mukhsonrofi.wordpress.com/2009/02/09/skandal-satyam-mengguncang-dunia/ (accessed mei 2017).

Website BI. n.d. www.wsa.bi.go.id (accessed 2017).

website IDX. n.d. www.idx.co.id (accessed 2017).

website BPK. n.d. http://www.bpk.go.id (accessed agustus 2017). 